\title{
Novel Survivin Inhibitor for Suppressing Pancreatic Cancer Cells Growth via Downregulating Sp1 and Sp3 Transcription Factors
}

\author{
Myrna Hurtado Umesh T. Sankpal $^{b} \quad$ Aboubacar Kaba $^{\mathrm{a}}$ Shahela Mahammad \\ Jaya Chhabrac Deondra T. Brownc Raj K. Gurung ${ }^{c}$ Alvin A. Holder \\ Jamboor K. Vishwanatha ${ }^{a}$ Riyaz Basha, \\ ${ }^{a}$ Graduate School of Biomedical Sciences, UNT Health Science Center, Fort Worth, ${ }^{b} T e x a s$ College \\ of Osteopathic Medicine, UNT Health Science Center, Fort Worth, 'Department of Chemistry and \\ Biochemistry Old Dominion University, Norfolk, USA
}

\section{Key Words}

Pancreatic cancer $\cdot \mathrm{Sp} 1 \cdot \mathrm{Sp} 3 \cdot$ Survivin $•$ Copper-tolfenamic acid

\begin{abstract}
Background/Aims: Targeting survivin, an anti-apoptotic protein and mitotic regulator, is considered as an effective therapeutic option for pancreatic cancer $(\mathrm{PaCa})$. Tolfenamic acid (TA) showed anti-cancer activity in pre-clinical studies. A recent discovery demonstrated a copper(II) complex of TA (Cu-TA) can result in higher activity. In this study, the ability of Cu-TA to inhibit survivin and its transcription factors, Specificity protein (Sp) 1 and 3 in PaCa cell lines and tumor growth in mouse xenograft model were evaluated. Methods: Cell growth inhibition was measured in MIA PaCa-2 and Panc1 cells for 2 days using CellTiter-Glo kit. Sp1, Sp3 and survivin expression (by Western blot and qPCR), apoptotic cells and cell cycle phase distribution (by flow cytometry) were evaluated. A pilot study was performed using athymic nude mice [treated with vehicle/Cu-TA ( 25 or $50 \mathrm{mg} / \mathrm{kg}$ ) 3 times/week for 4 weeks. Results: The $\mathrm{IC}_{50}$ value for Cu-TA was about half than TA.Both agents repressed the protein expression of Sp1/Sp3/ survivin, Cu-TA was more effective than TA. Especially effect on survivin inhibition was 5.2 (MIA PaCa-2) or 6.4 (Panc1) fold higher and mRNA expression of only survivin was decreased. Apoptotic cells increased with $\mathrm{Cu}$-TA treatment in both cell lines, while Panc1 showed both effect on apoptosis and cell cycle $\left(\mathrm{G}_{2} / \mathrm{M}\right)$ arrest. $\mathrm{Cu}$-TA decreased the tumor growth in mouse xenografts ( $25 \mathrm{mg} / \mathrm{kg}: 48 \% ; 50 \mathrm{mg} / \mathrm{kg}: 68 \%$ ). Additionally, there was no change observed in mice body weights, indicating no overt toxicity was occurring. Conclusion: These results show that $\mathrm{Cu}$-TA can serve as an effective survivin inhibitor for inhibiting PaCa cell growth.
\end{abstract}




\section{Cellular Physiology $\quad$ Cell Physiol Biochem 2018;51:1894-1907 \begin{tabular}{ll|l} 
and Biochemistry & $\begin{array}{l}\text { DOl: 10.1159/000495715 } \\
\text { Published online: } 1 \text { December } 2018\end{array}$ & $\begin{array}{l}\text { O 2018 The Author(s). Published by S. Karger AG, Basel } \\
\text { www.karger.com/cpb }\end{array}$ \\
\cline { 2 - 3 }
\end{tabular} \\ Hurtado et al.: Novel Survivin Inhibitor for Suppressing Pancreatic Cancer Cells}

\section{Introduction}

Over the last few decades, the cancer research community has grown immensely. Unfortunately, pancreatic cancer (PaCa) is one of the few cancers that has not made a significant improvement in terms of treatment and survival rates. In the U.S., PaCa is the $3^{\text {rd }}$ leading cause of cancer related deaths and is one of the most fatal malignancies due to its poor prognosis [1-3]. PaCa diagnosis generally occurs in the late stages, after the cancer has metastasized and is aggressive in nature. There are currently no early detection methods for this cancer; which contributes to its late diagnosis and thus treatment is quite difficult [4]. Current standard treatment for PaCa include surgery and chemotherapy along with radiation. However, because of its late diagnosis, surgery is a viable option to less than $20 \%$ of cases [5]. Chemotherapy drugs for PaCa include gemcitabine, 5-fluorouracil, cisplatin, and paclitaxel $[6,7]$. These cytotoxic therapies have a number of negative side effects including low blood count and peripheral neuropathy [8]. Certain chemotherapy drugs have additional side effects. For example, at higher dosages cisplatin can cause nerve and renal damage [9]. Notably, chemotherapy and radiation becomes less effective when the patient begins developing resistance over time $[10,11]$. Thus, there is an urgent need for alternative therapies that are more effective yet less harmful.

Survivin is encoded by the BIRC5 gene and part of the inhibitor of apoptosis protein family [12]. Increased expression of survivin is observed during fetal development, but in adult cells its expression is minimal [13]. Survivin's overexpression is considered to be a negative prognostic factor for patient survival $[14,15]$. Satoh et al., evaluated the clinical specimens of 56 patients and survivin was found to be over-expressed in $77 \%$ of pancreatic ductal carcinoma patients [16]. In another study, Lee et al., found that $94 \%$ of 49 patient samples were positive to survivin [17]. Furthermore, survivin was shown as a constitutive resistance factor for radiation [18] and knocking down of survivin via siRNA technology attenuated radiation resistance [19]. Since the association of survivin with $\mathrm{PaCa}$ and the response to $\mathrm{PaCa}$ treatment is well established, it is ideal to exploring the agents that can target survivin and can induce anti-cancer activity.

Tolfenamic acid (TA) is classified as a non-steroidal anti-inflammatory drug (NSAID) and is used as a generic drug to treat migraines in Europe. Studies from our laboratory and others have demonstrated that TA contains anti-cancer properties such as cancer cell growth inhibition and induction of apoptosis in pre-clinical models, including PaCa [20-23]. Konduri et al. (2009) also demonstrated that TA sensitizes PaCa cells and tumors in mice (orthotopic model) to radiation [24]. TA has been shown to work through downregulation of Specificity proteins 1 and 3 (Sp1 and Sp3) [20]. They can regulate their target gene transcription by binding to GC-rich elements and promoter sequences. Sp1 overexpression is associated with tumor formation and progression, metastasis, and angiogenesis [25]. Therefore, it has even been suggested as a potential biomarker to detect a class of advanced pancreatic ductal adenocarcinoma [26].

One gene of particular interest in PaCa regulated by these Sp1 and Sp3 is survivin [27]. For these reasons, TA is an attractive potential chemotherapeutic for PaCa since it targets Sp1, Sp3, and survivin. TA has been approved for Phase I Clinical Trials along with radiation and gemcitabine treatment for PaCa. However, since the dosage for TA's anti-cancer activities is slightly high $(50 \mu \mathrm{M})$, strategies to enhance its efficacy is important. Therefore, we began to look into using a TA derivative, specifically, a metallodrug. Metal complexes have been found to have a synergistic activity with their original drugs which enhance the drug's bioactivity [28-34]. Recently, a copper (II)-Tolfenamic acid has been synthesized and published [35]. We have recently evaluated the anti-proliferative activity of $\mathrm{Cu}(\mathrm{II})$ - containing complex of TA (Cu-TA) Cu-TA using twelve human cancer cells lines representing six cancers [36]. This screening study found that TA was chemically and biologically stable and demonstrated a higher efficacy in comparison to TA. Additionally, there was no overt toxicity observed in the 


\section{Cellular Physiology Cell Physiol Biochem 2018;51:1894-1907

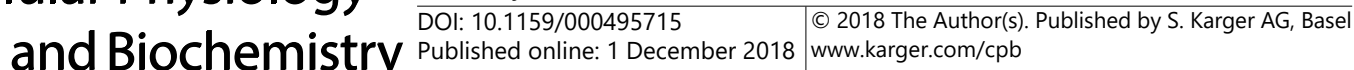

$\mathrm{Cu}-\mathrm{TA}$ treated cardiomyocytes. In this study, we assessed the anti-cancer efficacy of Cu-TA in detail using human PaCa cell lines. The results of this study showed higher anti-cancer activity of $\mathrm{Cu}$-TA which was accompanied by a substantially higher increase in the inhibition of survivin when compared to TA.

\section{Materials and Methods}

\section{Cell lines and Culture Conditions}

Two human pancreatic ductal adenocarcinoma cell lines, MIA PaCa-2 and Panc1were obtained American Type Culture Collection (ATCC) and authenticated using STR profiling by ATCC in July, 2018. Both cell lines resulted in 100\% match with the ATCC database. Both cell lines were grown and cultivated in Dulbecco's Modified Eagle Medium (DMEM) media with high glucose (4500 mg/L) supplemented with 5\% fetal bovine serum and $1 \%$ penicillin streptomycin. Cells were maintained in an incubator at $37^{\circ} \mathrm{C}$ with $5 \%$ $\mathrm{CO}_{2}$.

\section{Preparation of Stock Concentrations}

Tolfenamic acid was purchased from Sigma-Aldrich Corporation and a $10 \mathrm{mM}$ stock solution was prepared in dimethyl sulfoxide (DMSO). Commercially available copper(II) chloride $\left(\mathrm{CuCl}_{2}\right)$ and 2, 2'-bipyridine (bpy) were used as controls. The copper(II)-tolfenamic acid (Cu-TA) complex was synthesized using an established method [35]. A $10 \mathrm{mM}$ stock solution of $\mathrm{CuCl}_{2}$, BPY, and $\mathrm{Cu}$-TA were all prepared in DMSO.

\section{Cell Viability}

MIA PaCa-2 and Panc1 cells were seeded in 96-well plates with each well containing 4, 000 cells in $50 \mu \mathrm{l}$ of media. $10 \mathrm{mM}$ stock concentrations of each drug were diluted in $50 \mu \mathrm{l}$ of media before treatment. Each treatment was carried out in triplicates with increasing concentrations of DMSO (vehicle), TA (10, 25, 50 , and $100 \mu \mathrm{M})$, or Cu-TA $(10,25$, and $50 \mu \mathrm{M})$. Cells were then incubated with CellTiter-Glo reagent 24 and $48 \mathrm{~h}$ post-treatment and incubated in the dark for $25 \mathrm{~min}$. Cell viability was then measured by detecting luminescence using Synergy HT (BioTek) plate reader. For all subsequent experiments the concentration of Cu-TA's $\mathrm{IC}_{50}$ value and equimolar TA were used. To test the cytotoxic effect of the components used in the synthesis of $\mathrm{Cu}-\mathrm{TA}\left(\mathrm{CuCl}_{2}\right.$ and BPY), MIA PaCa-2 and Panc1 cells were treated with DMSO, $\mathrm{CuCl}_{2}$ or BPY using equimolar concentration of Cu-TA's IC $_{50}$ value (MIA PaCa-2: $29 \mu \mathrm{M}$; Panc1: $27 \mu \mathrm{M}$ ). Cell viability was measured as explained above.

\section{Caspase 3/7 Assay}

MIA PaCa-2 and Panc1 cells were seeded in 96-well plates with each well containing 4, 000 cells in 50 $\mu \mathrm{l}$ of media. $10 \mathrm{mM}$ stock concentrations of each drug were diluted in $50 \mu \mathrm{l}$ of media before treatment, with each treatment done in triplicates. The activation of caspase 3 and 7 was measured using Caspase-Glo 3/7 kit (Promega). Cells were plated in a 96-well plate and then treated with DMSO (control), Cu-TA (MIA PaCa2: $29 \mu \mathrm{M}$; Panc1: $27 \mu \mathrm{M}$ ) or equimolar TA. At 24 and $48 \mathrm{~h}$, samples were incubated with Caspase 3/7-Glo substrate for $1 \mathrm{~h}$ in the dark and then read by Synergy HT (BioTek) plate reader.

\section{Western Blot}

MIA PaCa-2 and Panc1 cells were plated in $10 \mathrm{~cm}$ petri dishes containing 750, 000 cells in $10 \mathrm{ml}$ of media. Cell were treated with either DMSO, Cu-TA (MIA PaCa-2: 29 $\mu$ M; Panc1: $27 \mu \mathrm{M}$ ) or equimolar TA. After 24 and $48 \mathrm{~h}$ treatments, cell lysates were collected and prepared. Total cellular protein was extracted using cell lysis buffer and protein quantification was done using the Pierce BCA Protein Assay Kit (Thermo Scientific, Waltham, MA). Protein samples were then separated through $10 \%$ sodium dodecyl sulfate-polyacrylamide gel and then transferred to a nitrocellulose membrane. Next, the membranes were blocked with 5\% milk in Tris-Buffered Saline with $1 \%$ Tween. Blots were incubated with primary antibody overnight and incubated with secondary antibody for one hour the following day. Bands were detected using SuperSignal West Dura Extended Duration Substrate (Thermo Scientific). Protein expression of Sp1 (Santa Cruz Biotechnology, Dallas, TX), Sp3 (Santa Cruz Biotechnology), cleaved PARP (Cell Signaling Technology, 


\section{Cellular Physiology Cell Physiol Biochem 2018;51:1894-1907

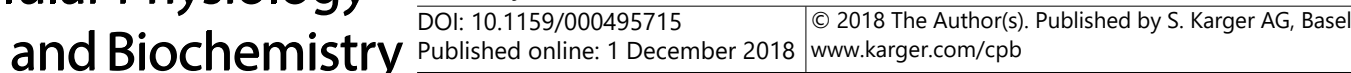 \\ Hurtado et al.: Novel Survivin Inhibitor for Suppressing Pancreatic Cancer Cells}

Danvers, MA), survivin (R\&D Systems, Minneapolis, MN), cyclin B1 (Cell Signaling Technology), and cyclin A (Cell Signaling Technology) were evaluated using specific antibodies while the expression of $\beta$-actin (SigmaAldrich Corporation) was used as a loading control.

\section{Quantitative Polymerase Chain Reaction ( $q P C R$ )}

MIA PaCa-2 and Panc1 cells were plated in $10 \mathrm{~cm}$ petri dishes containing 750, 000 cells in $10 \mathrm{ml}$ of media. Cells were treated with DMSO (control), Cu-TA (MIA PaCa-2: $29 \mu \mathrm{M}$; Panc1: $27 \mu \mathrm{M}$ ) or equimolar TA for $48 \mathrm{~h}$. At the time of collection, total RNA was extracted from treated cells using TRIzol (Invitrogen). Total RNA was then converted into single-stranded cDNA using Superscript III (Invitrogen). After cDNA amplification, genes were probed for using TaqMan Gene Expression Assays (Applied Biosystems) and samples were placed in a 96-well LightCycler 96 Real-Time PCR system (Roche) for qPCR analysis. Each sample was done in triplicates and GAPDH was used as a housekeeping gene.

\section{Flow cytometry}

PE Annexin V Staining: Apoptotic cell populations were detected using PE Annexin V Apoptosis Detection Kit I (BD Biosciences). Cells were plated in 6-well plates containing 2, 000 cells in 2 ml of media. Cells were treated with DMSO, Cu-TA (MIA PaCa-2: $29 \mu \mathrm{M}$; Panc1: $27 \mu \mathrm{M}$ ) or equimolar TA for 24 and $48 \mathrm{~h}$. Samples were collected, washed with PBS, and then incubated with Annexin V-PE/7-AAD solution for 15 min in the dark. Apoptotic cell populations were measured via FC500 flow cytometer.

\section{Cell Cycle Arrest}

MIA PaCa-2 and Panc1 cells were plated in 6-well plates containing 2, 000 cells in 2 ml of media. Cells were reated with DMSO (control), Cu-TA (MIA PaCa-2: $29 \mu \mathrm{M}$; Panc1: $27 \mu \mathrm{M}$ ) or equimolar TA then collected at 24 and 48 h post-treatment. Samples were collected, washed with PBS, fixed with cold 70\% ethanol and then stored in $-80^{\circ} \mathrm{C}$ overnight. The collected samples were then incubated with propidium iodide(PI)/ RNAse solution for DNA staining for $15 \mathrm{~min}$ at room temperature in the dark. Finally, samples were then incubated in $37^{\circ} \mathrm{C}$ for $10 \mathrm{~min}$. The cell cycle phase distribution was analyzed using FC500 Flow Cytometer.

\section{Mouse Model}

Athymic nu/nu nude mice were obtained from Charles River (Wilmington, MA). Mice were subcutaneously injected with $6 \times 10^{6}$ MIA PaCa-2 cells and the tumors were allowed to grow for 10 days $\left(\sim 100 \mathrm{~mm}^{3}\right.$ in diameter) before starting treatments. There were 3 treatment groups [vehicle (corn oil), CuTA $25 \mathrm{mg} / \mathrm{kg}$ or $50 \mathrm{mg} / \mathrm{kg}$ ] with 4 mice in each group (half male and half female). Mice were treated 3 times/ week for 4 weeks through oral gavage. Mouse body weights were recorded 3 times/week as well. At the end of 4 weeks, the mice were euthanized by $\mathrm{CO}_{2}$ asphyxiation and their tumors were harvested. The tumor volume and weights were measured and the averages in each group were calculated $(n=6)$. The procedures are approved by the Institutional Animal Care and Use Committee of the University of North Texas Health Science Center (protocol\# IACUC-2017-0040).

Statistical Analysis

Data were analyzed using one-way ANOVA. Results were expressed as mean \pm SD. Significance between treated and untreated cells were evaluated, and a $p$ value $<0.05$ was considered as significant.

\section{Results}

\section{TA and Cu-TA Inhibit PaCa Cell Growth}

MIA PaCa-2 and Panc1 cells were treated with increasing concentrations of DMSO, TA and $\mathrm{Cu}$-TA to evaluate the anti-proliferative activity and determine the optimal dosage for $\mathrm{Cu}$ TA. Both TA and $\mathrm{Cu}-\mathrm{TA}$ decreased cell viability in a dose and time dependent manner in both MIA PaCa-2 (Fig. 1A) and Panc1 cells (Fig. 1B). However, Cu-TA was found to be more effective than TA for inhibiting PaCa cell growth and at lower doses. The $\mathrm{IC}_{50}$ value for $\mathrm{Cu}-\mathrm{TA}$ at $48 \mathrm{~h}$ post-treatment (Fig. 1C) was found to be half (MIA PaCa-2: $29.32 \mu \mathrm{M}$; Panc1: $26.65 \mu \mathrm{M}$ ) that of TA's IC ${ }_{50}$ value (MIA PaCa-2: $57.20 \mu \mathrm{M}$; Panc1: $61.76 \mu \mathrm{M}$ ). At $24 \mathrm{~h}$, there was less than $50 \%$ 
A

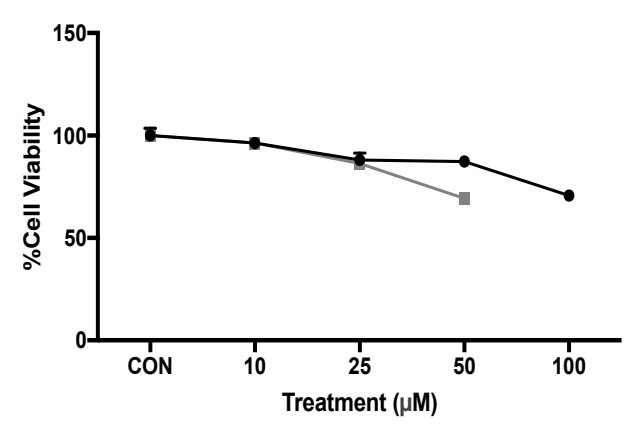

B

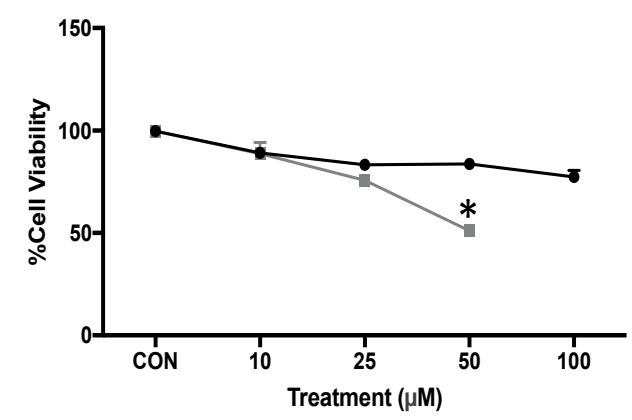

MIA PaCa-2: $48 \mathrm{~h}$

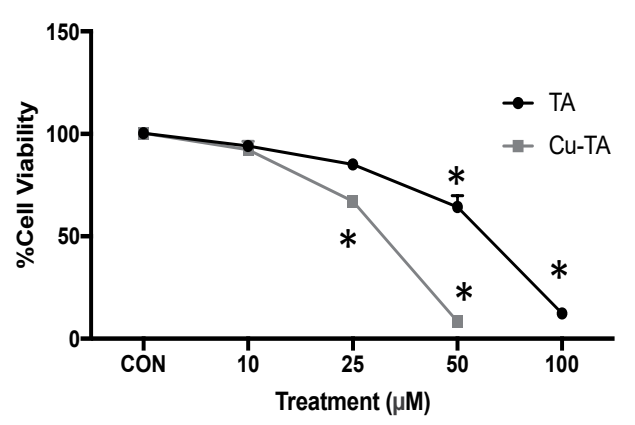

Panc1: $48 \mathrm{~h}$

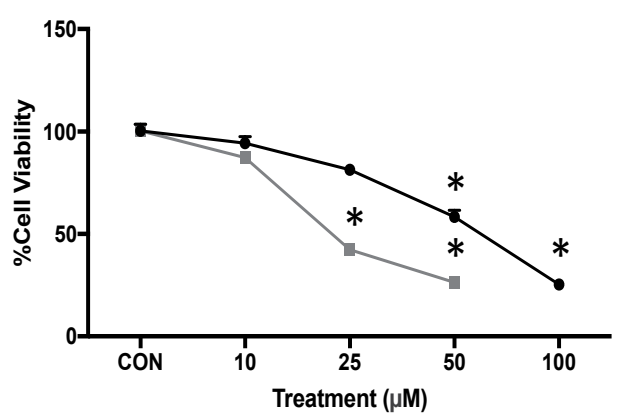

C

\begin{tabular}{|l|c|c|c|}
\hline Cell line & $\mathbf{I C}_{50}$ Value TA & $\mathbf{I C}_{\mathbf{5 0}}$ Value Cu-TA & \% Less with TA \\
\hline MIA PaCa-2 & $57.20 \mu \mathrm{M}$ & $29.32 \mu \mathrm{M}$ & 43.5 \\
\hline Panc1 & $61.76 \mu \mathrm{M}$ & $26.65 \mu \mathrm{M}$ & 56.8 \\
\hline
\end{tabular}

D

MIA PaCa-2

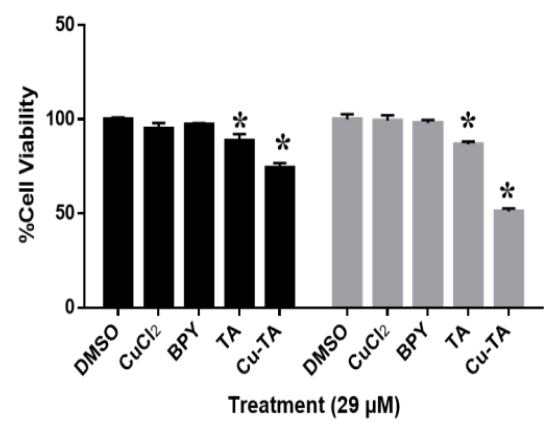

Panc1

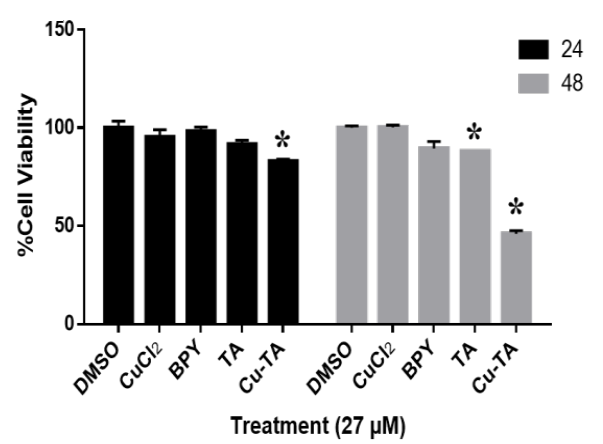

Fig. 1. Anti-proliferative effect of TA or Cu-TA against PaCa cells. MIA PaCa-2 (A) and Panc1 (B) cells were treated with DMSO or Cu-TA $(5-50 \mu \mathrm{M})$ or TA $(5-100 \mu \mathrm{M})$ and cell viability was measured after 24 and 48 h. Lines represent $\%$ viable cells (mean \pm SD) normalized to control. All treatments were done in triplicate. (C) $\mathrm{IC}_{50}$ values for both cell lines at $48 \mathrm{~h}$ for TA and $\mathrm{Cu}-\mathrm{TA}$. (D) The effect of $\mathrm{CuCl}_{2}$ and BPY on cell viability in MIA PaCa-2 and Panc1 cells was measured 24 and 48 h post-treatment. Bars represent \% viable cells (mean \pm SD) normalized to control. All treatments were done in triplicate, and the bars marked with '*' are significantly different from corresponding control $(\mathrm{p}<0.0001)$. 
cell growth inhibition for both cell lines. Therefore, the $\mathrm{IC}_{50}$ values were calculated only at 48 $\mathrm{h}$ post-treatment and found that $\mathrm{Cu}-\mathrm{TA}^{\prime} \mathrm{IC}_{50}$ values were $49 \%$ and $57 \%$ less (respectively in MIA PaCa-2 and Panc1) when compared to TA. Additionally, neither $\mathrm{CuCl}_{2}$ nor BPY had any effect on cell viability (Fig. 1D).

\section{Cu-TA Downregulates Sp1, Sp3 and Survivin Protein Expression}

The effect of $\mathrm{Cu}-\mathrm{TA}$ on $\mathrm{Sp} 1, \mathrm{Sp} 3$ and survivin protein expression was assessed via Western blot. There was a significant inhibition of Sp1, Sp3 and survivin protein expression with the $\mathrm{Cu}-\mathrm{TA} 48 \mathrm{~h}$ treatment in both cell lines (Fig. 2A\&B). TA is known to downregulate $\mathrm{Sp} 1, \mathrm{Sp} 3$ and survivin protein expression, however, at the equimolar dosage of $\mathrm{Cu}-\mathrm{TA}^{\prime} \mathrm{S} \mathrm{IC}_{50}$ value there was no change.

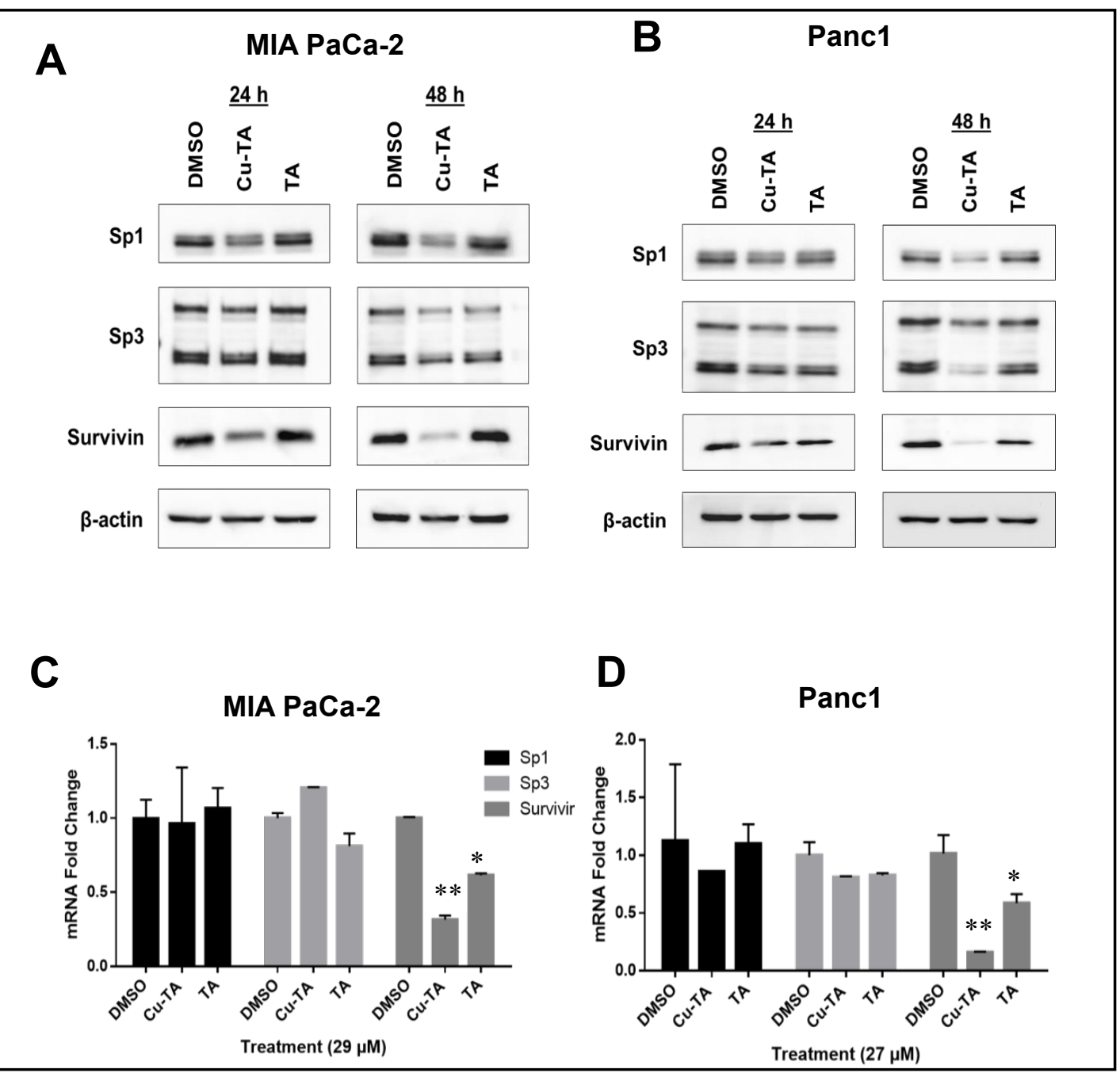

Fig. 2. Effect of $\mathrm{Cu}-\mathrm{TA}$ on $\mathrm{Sp} 1, \mathrm{Sp} 3$ and survivin expression in PaCa cells. (A\&B) MIA PaCa-2 and Panc1 cells were treated with DMSO, Cu-TA (MIA PaCa-2: $29 \mu \mathrm{M}$; Panc1: $27 \mu \mathrm{M}$ ) or equimolar TA for 24 and 48 h. Protein extracts from cell lysates were then prepared and the expression of Sp1, Sp3, survivin, and $\beta$-actin (loading control) was determined by Western blot analysis. All experiments were conducted with 3 sets of samples and the representative gels are shown in the Figure. (C\&D) MIA PaCa-2 and Panc1 cells were treated with DMSO or Cu-TA (MIA PaCa-2: $29 \mu \mathrm{M}$; Panc1: $27 \mu \mathrm{M}$ ) or equimolar TA for $48 \mathrm{~h}$. Total RNA was then extracted and mRNA expression levels of Sp1, Sp3 and survivin were assessed via qPCR. GAPDH was used as a housekeeping gene. Bars represent mRNA fold change (mean \pm SD) normalized to control. All treatments were done in triplicates, and the bars marked with '*' are significantly different from corresponding control $(\mathrm{P}<0.001)$. 
TA and Cu-TA Lower Survivin mRNA Expression Levels While Sp1 and Sp3 Remains Unaltered

Quantitative PCR results demonstrate that TA and Cu-TA treatments significantly lower survivin mRNA expression levels in both cell lines (Fig. 2C\&D). This indicates that survivin is effected at the transcriptional level. However, Sp1 and Sp3 mRNA expression levels remain relatively unchanged in both cell lines.

\section{Cu-TA Increases Apoptotic Markers and Apoptotic Cell Populations}

Cells were treated with Cu-TA or TA and their effect on effector caspase 3/7 activity, protein expression of c-PARP and apoptotic cell populations were analyzed. Cu-TA treated cells had a significant increase in effector caspase $3 / 7$ activity and this correlated with an increase in c-PARP expression (Fig. 3). A significant increase in apoptotic cell populations was also observed for the $\mathrm{Cu}$-TA treatment (Fig. 4).

\section{Cu-TA Causes G2/M Phase Arrest in Panc1 Cells}

$\mathrm{Cu}-\mathrm{TA}$ 's effect on cell cycle phase distribution was determined by flow cytometric analysis. Cu-TA had no effect on MIA PaCa-2 cells (Fig. 5A), while there was an increase in G2/M phase in Panc1 cells (Fig. 5B; Fig. 6A) at 48 h. Confirmation of G2/M phase arrest was done by examining protein expression of G2/M markers, cyclin B1 and cyclin A (Fig. 6B).

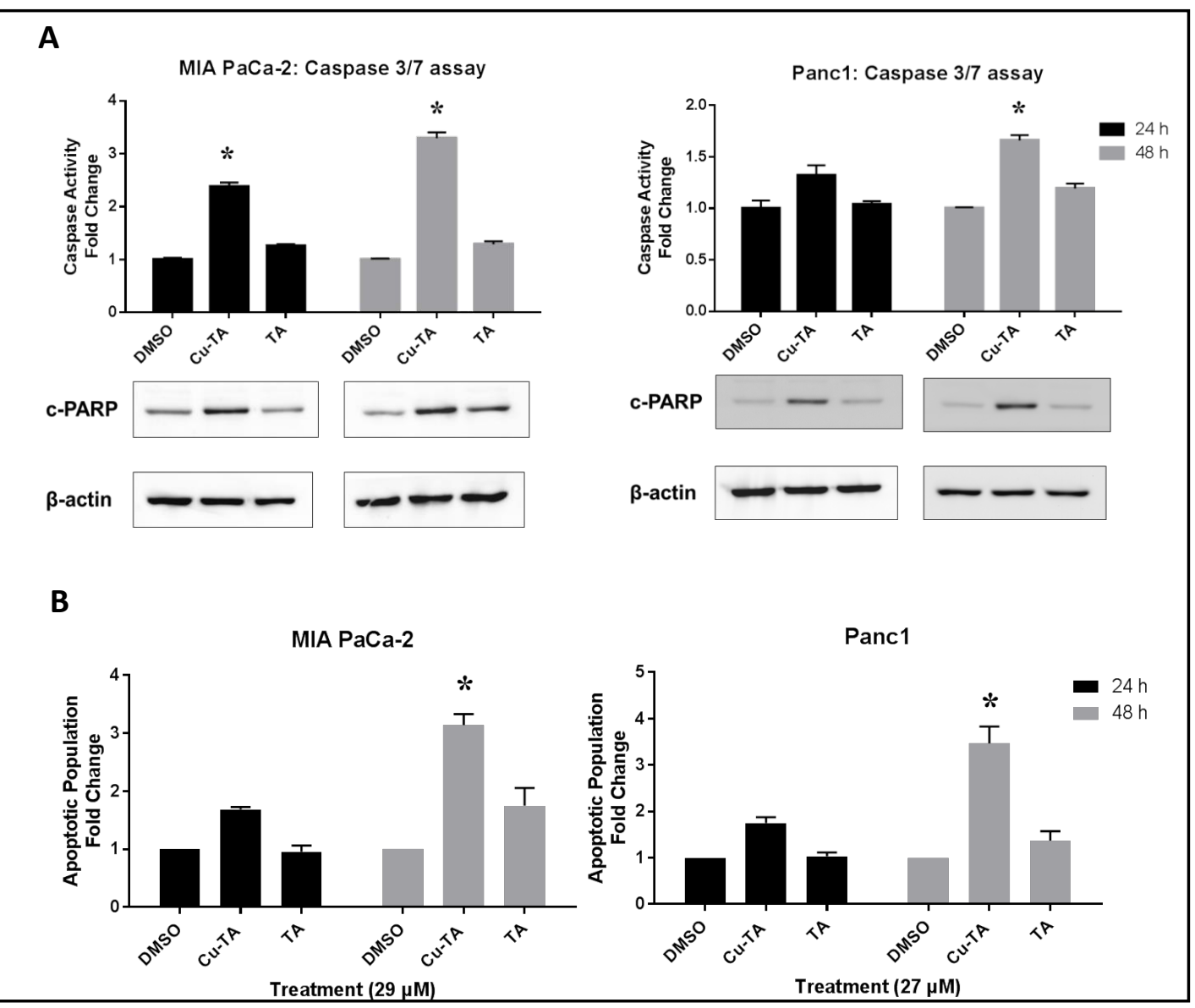

Fig. 3. $\mathrm{Cu}-\mathrm{TA}$ upregulates effector caspase activity, cleaved PARP expression, and apoptotic cell populations in PaCa cells. (A) MIA PaCa-2 and Panc1 cells were treated with DMSO, Cu-TA (MIA PaCa-2: $29 \mu$ M; Panc1: $27 \mu \mathrm{M}$ ) or equimolar TA. Caspase 3/7 activity and c-PARP protein expression was determined at 24 and 48 $\mathrm{h}$ post-treatment. (B) shows the fold change of apoptotic cell populations in MIA PaCa-2 and Panc1. Bars represent mean \pm SD. All treatments were done in triplicates, and the bars marked with '*' are significantly different from corresponding control $(\mathrm{p}<0.001)$. 
A
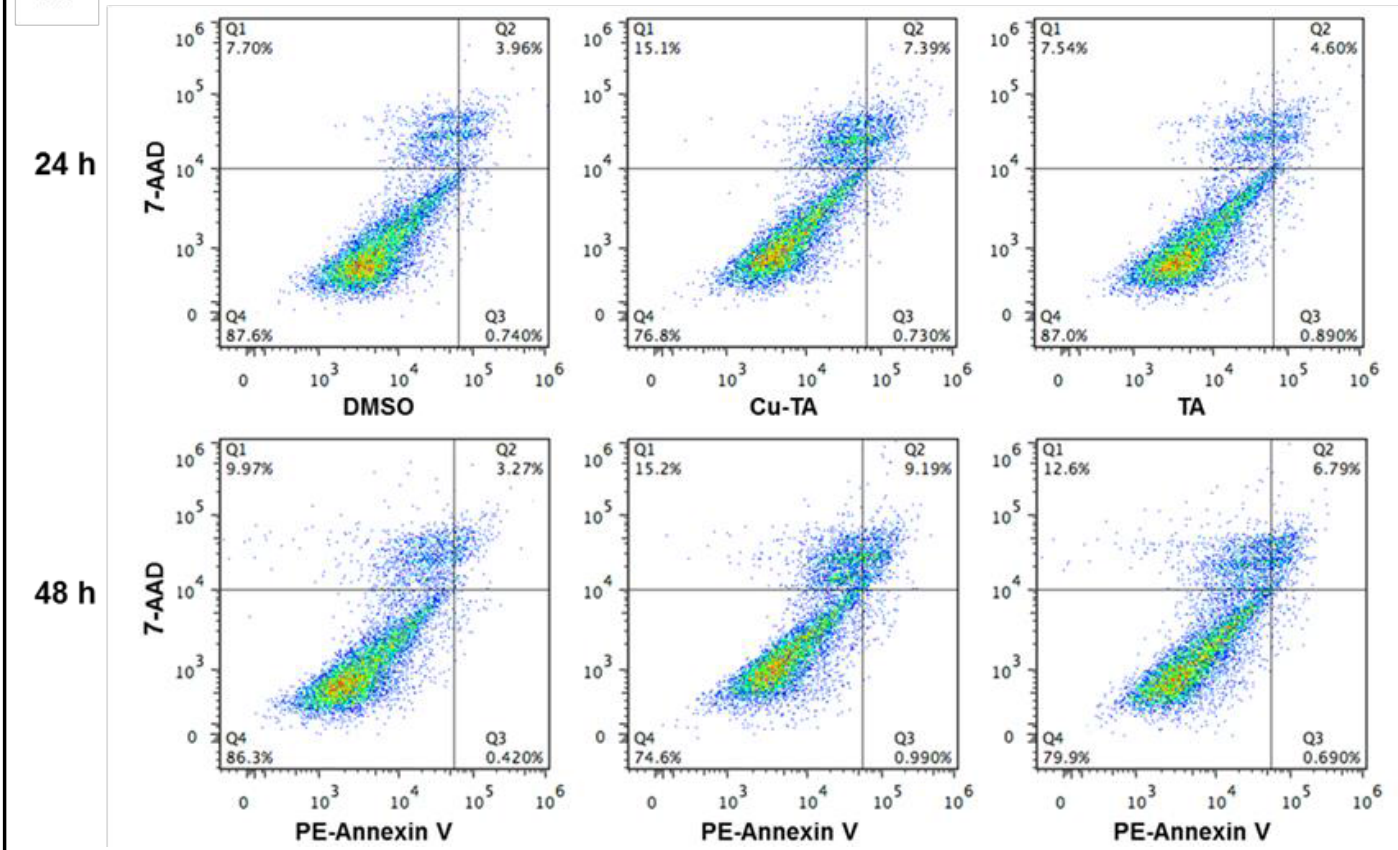

B
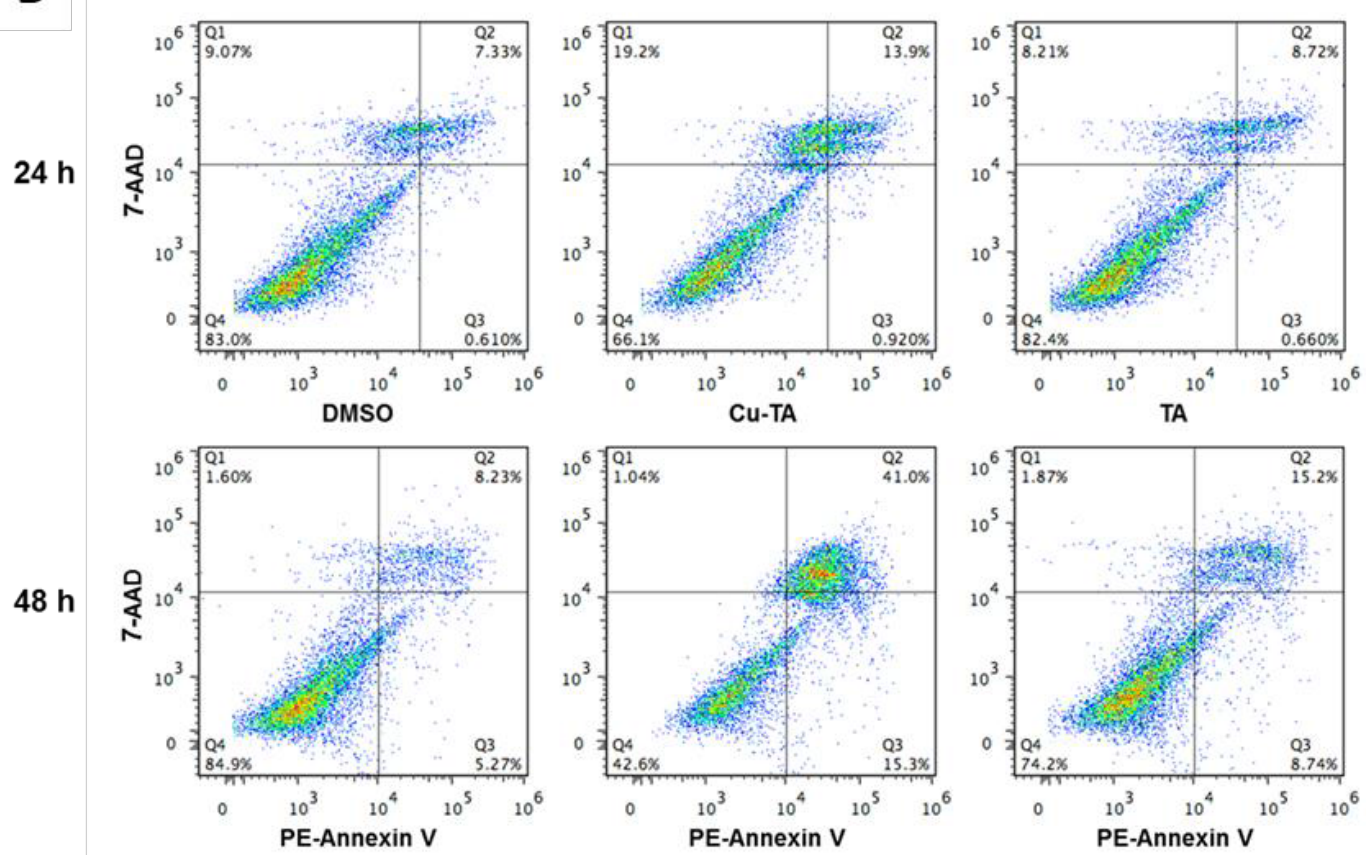

Fig. 4. Cu-TA increases apoptotic cell populations in PaCa cells. (A) MIA PaCa-2 and (B) Panc1 cells were treated with DMSO, Cu-TA (MIA PaCa-2: $29 \mu \mathrm{M}$; Panc1: $27 \mu \mathrm{M}$ ) or equimolar TA. Apoptotic cell populations were assessed using PE Annexin V Staining post 24 and $48 \mathrm{~h}$ treatment. 

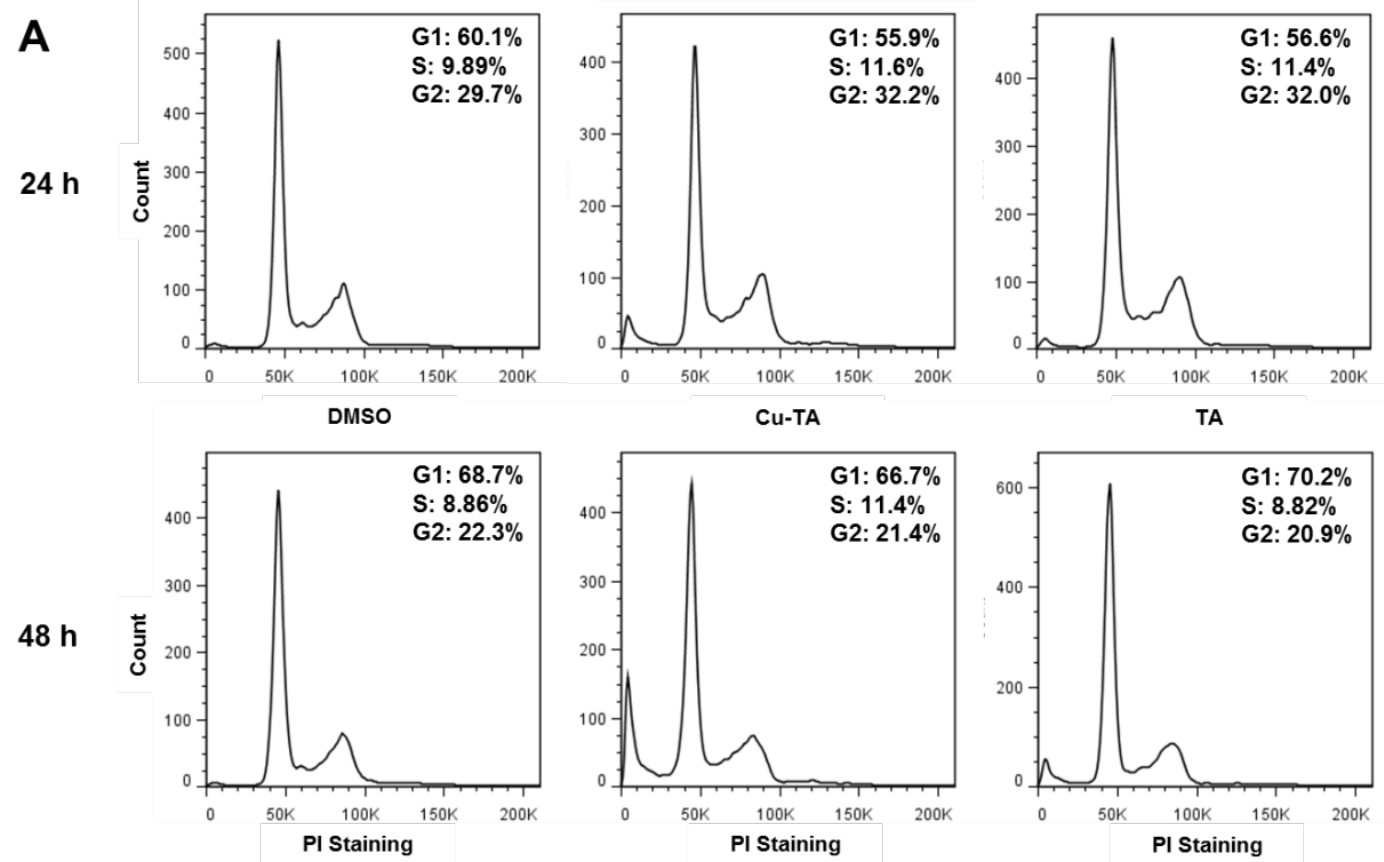

B
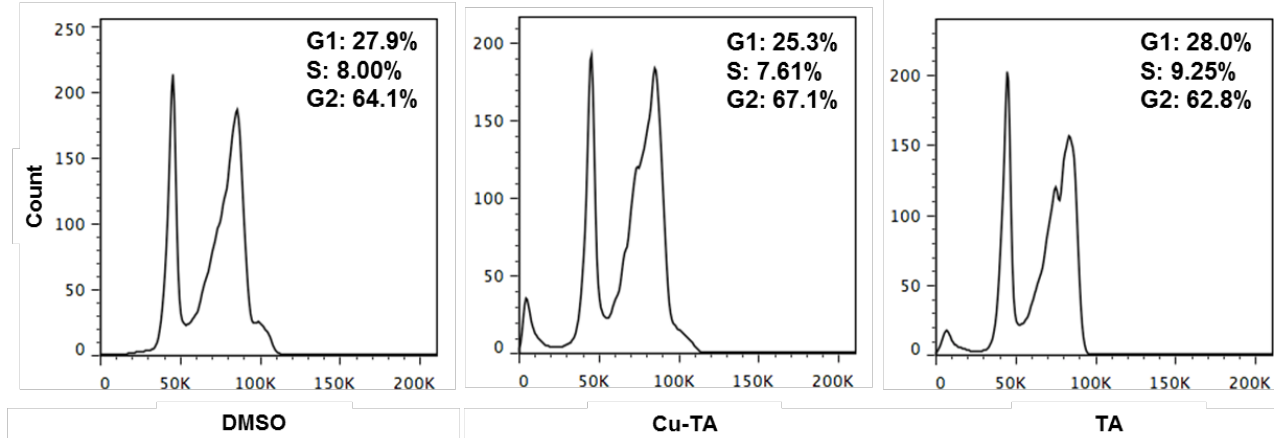

$24 \mathrm{~h}$
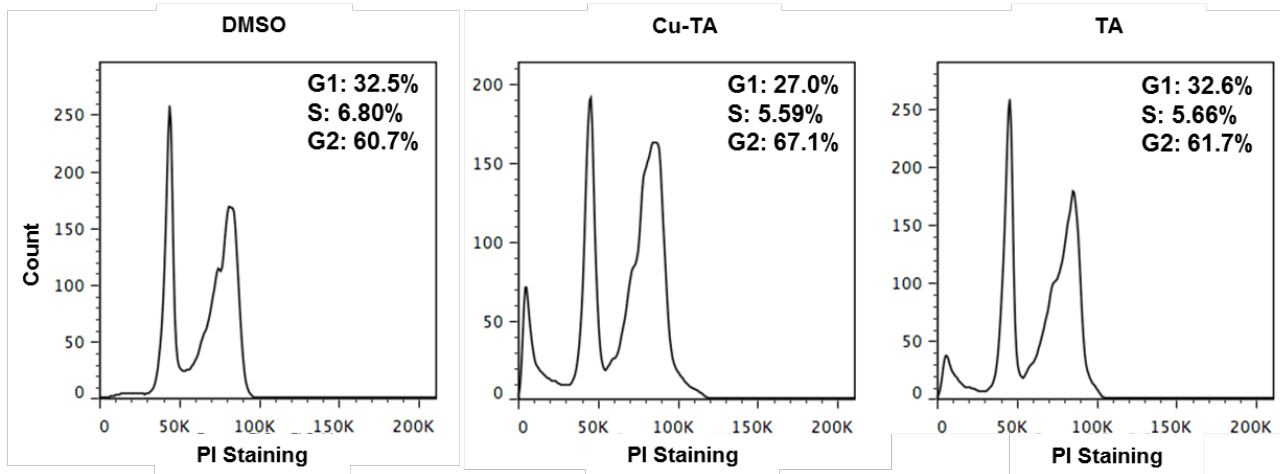

Fig. 5. $\mathrm{Cu}$-TA causes G2/M phase arrest in Panc1 cells. (A) MIA PaCa-2 and (B) Panc1 cells were treated with DMSO, Cu-TA (MIA PaCa-2: $29 \mu \mathrm{M}$; Panc1: $27 \mu \mathrm{M}$ ) or equimolar TA for 24 and $48 \mathrm{~h}$ post-treatment. Cells were collected and then incubated with propidium iodide DNA staining. Samples were then analyzed via flow cytometry. Peaks indicate respective phase $\left(G_{0}, S, G_{2} / M\right)$ of the cell cycle. 
Fig. 6. Confirmation of $\mathrm{G} 2 / \mathrm{M}$ phase arrest in Panc1 cells. (A) Panc1 cells were treated with DMSO, Cu-TA $(27 \mu \mathrm{M})$ or equimolar TA for $48 \mathrm{~h}$. Cells were collected and then incubated with propidium iodide DNA staining. Samples were then analyzed via flow cytometry. Bars represent \% cells in a particular cell cycle phase (mean \pm SD) normalized to control. All treatments were done in triplicate, and the bars marked

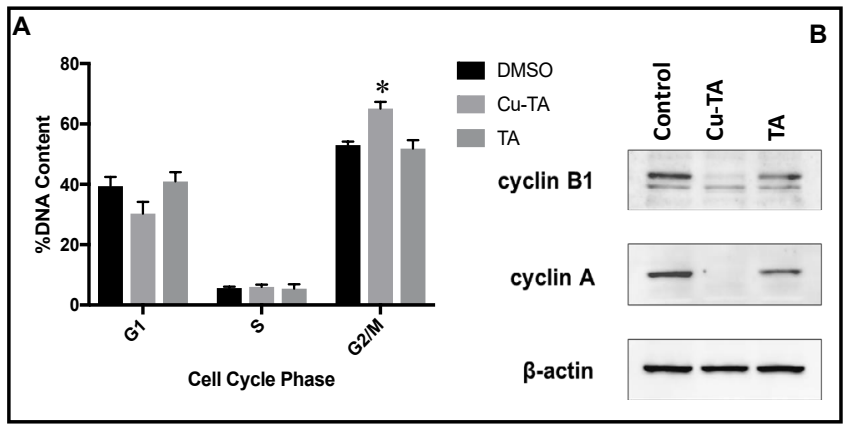
with ' $*$ ' are significantly different from corresponding control $(\mathrm{p}<0.05)$. (B) Protein extracts from Panc1 cell lysates were then prepared and the expression of $G_{2} / M$ phase markers cyclin $B 1$, cyclin $A$ and $\beta$-actin was determined by Western blot analysis.

\section{Cu-TA Dose Dependently Inhibits Tumor Growth in PaCa Mouse Model \\ Both $\mathrm{Cu}-\mathrm{TA}$ treatment} groups caused a decrease in tumor weights and volume which appears to be a dose dependent response. The $\mathrm{Cu}-\mathrm{TA} 25 \mathrm{mg} / \mathrm{kg}$ group had a $48 \%$ decrease while the $50 \mathrm{mg} / \mathrm{kg}$ group had a $68 \%$ decrease in tumor weight (Fig. 7A). Tumor volume also showed similar trend showing 39\% (25 mg/kg group) and $73 \%$ decrease (50 mg/kg group) decrease when compared to control group (Fig. 7B). In addition, there was a decrease in tumor vasculature as pictured (insert) in Fig. 7A. There was no change in mice body weights (Fig. 7C), indicating no overt toxicity.

\section{Discussion}

The limited treatment options and therapy effectiveness pose a crucial need for novel treatments for PaCa. for their transformation and subsequent progression and resistance to radiation/chemotherapy [37]. Resistance to current therapeutic options is a major barrier in PaCa treatment. Therefore, an effective approach for treatment could be targeting the molecular mechanisms that drive tumorigenesis and resistance. In this study, we were particularly interested in survivin because of its known role in poor prognosis and resistance to treatment in PaCa. Due to morbidity associated with standard care, it is not plausible to increase the doses when the patients show poor response, thereby treatment of such patients is becoming even more challenging. Therefore, the strategies to identify less toxic agents to induce sensitivity in cancer cells and the therapeutic efficacy is our top priority. There have been an increasing

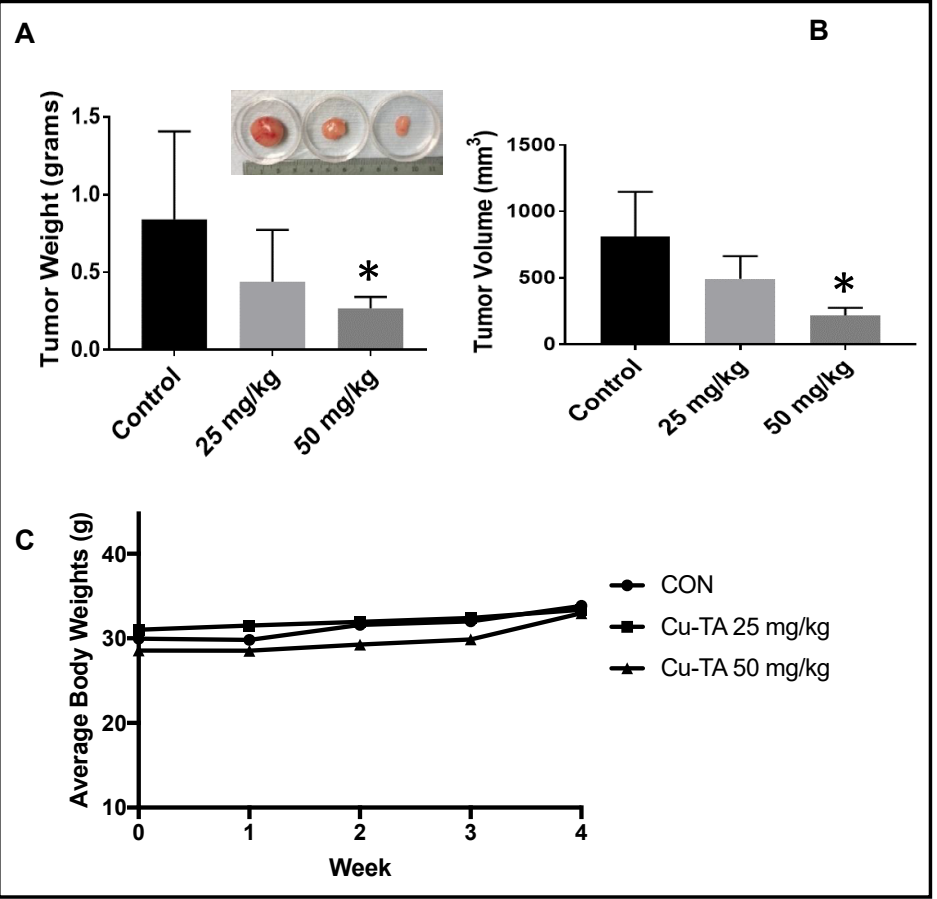

Fig. 7. $\mathrm{Cu}-\mathrm{TA}$ inhibits $\mathrm{PaCa}$ tumor growth in mouse: Athymic nude mice were injected with 6 million MIA PaCa-2 cells and were treated with either vehicle (corn oil), Cu-TA $25 \mathrm{mg} / \mathrm{kg}$ or $50 \mathrm{mg} / \mathrm{kg} 3$ times/week for 4 weeks. Mean $( \pm S E)$ of (A) tumor weight and (B) tumor volume (representative tumor pictures in the insert) of the mice treated with vehicle or $25 \mathrm{mg} / \mathrm{kg}$ of $\mathrm{Cu}-\mathrm{TA}$ or $50 \mathrm{mg} / \mathrm{kg}$ of $\mathrm{Cu}-\mathrm{TA}$ ( $\mathrm{n}=6$ per group). (C) The body weights were measured each week and the weight (mean \pm SD) of animals were presented. 
number of studies using NSAIDs as chemopreventive and chemotherapeutic agents [38], because NSAIDs are not only effective, but also less toxic in comparison to conventional chemotherapy drugs [39]. Several strategies including small molecules for inhibiting cell growth pathways have been tested $[40,41]$. NSAIDs are small molecules that typically work by inhibiting cyclooxygenase (COX) enzymes and thereby modulating prostaglandins [42]. However, there are limitations to the use of NSAIDs for cancer therapy especially the issues associated with long-term use [43]. Therefore, there has been rising interest in finding NSAIDs that work independent of COX enzyme inhibition.

Our laboratory and others have demonstrated the effectiveness of TA (NSAID) for inhibiting PaCa cell growth in cancer models $[20,24,44]$. In this study, the cell viability results demonstrated that $\mathrm{Cu}$-TA's anti-proliferative effect in $\mathrm{PaCa}$ cells is much more effective resulting the $\mathrm{IC}_{50}$ value about $50 \%$ less than TA in both cell lines (Fig. 1A\&B). Furthermore, neither $\mathrm{CuCl}_{2}$ nor BPY had any significant effect on cell growth in either cell line at 24 and $48 \mathrm{~h}$ post-treatment (Fig. 1C). This demonstrates that the decrease in cell viability is specific to the $\mathrm{Cu}$-TA compound and not to any single agent alone. Protein analysis showed that $\mathrm{Cu}$ TA treatment caused downregulation of Sp1, Sp3 and survivin (Fig. 2A\&B). To investigate if this downregulation was due to the targets being effected on a transcriptional level or post-translationally, mRNA levels were examined. Survivin was found to be significantly downregulated on a transcriptional level while both Sp1 and Sp3 levels were comparatively unaffected (Fig. 2C\&D) suggesting that significant decrease of survivin mRNA levels could be due to a lack of Sp1- and Sp3-dependent transcription [27]. These results correspond with previous TA data; TA is known to effect Sp1 and Sp3 post-translationally, through proteasome-dependent degradation [24]. This suggests that $\mathrm{Cu}$-TA perhaps work in a similar mechanism to TA.

To investigate the cause of growth inhibitory response seen in the $\mathrm{Cu}$-TA treatment, the apoptotic markers, caspase 3/7 and c-PARP and the number of apoptotic cells were evaluated. Thus, the increased caspase $3 / 7$ activity and protein expression of c-PARP in the $\mathrm{Cu}-\mathrm{TA}$ treatment suggests that the activation of apoptosis is occurring (Fig. 3A). Annexin-V has a high affinity for PS, thus, when linked to the fluorochrome phycoerythrin (PE), it is possible to detect apoptotic cell populations via flow cytometry [45]. Annexin-V flow cytometric results showed Cu-TA significantly increased apoptotic cell populations (Fig. 3A; Fig. 4), correlating with the increased caspase activity and cleaved PARP expression (Fig. $3 \mathrm{~A})$.

Cell cycle phase distribution was also examined. The $\mathrm{Cu}$-TA treatment in Panc1 cells revealed an increase in G2/M phase cells compared to the control, indicating cell cycle arrest (Fig. 5B; Fig. 6A). Cell cycle is a highly regulated process involving a series of events that leads to faithful replication of cells. The transition and progression of cell cycle phase depends on differential expression of various cyclins [46]. Cyclins form complexes with their respective cyclin-dependent kinases (CDKs) which can then regulate transcription of target genes [47]. The expression of cyclin A and B1 were evaluated because of their function and accumulation in G2/M phase transition [48, 49]. Downregulation of both cyclins confirmed cell cycle arrest results. This G2/M phase arrest caused by Cu-TA may be partially responsible for the growth inhibitory response in Panc1 cells. There was no cell cycle arrest observed in MIA PaCa-2 cells at either time point studied. $\mathrm{Cu}$-TA could perhaps be predominantly affecting apoptotic pathways rather than cell cycle arrest in MIA PaCa-2 cells. Next Generation Sequencing analysis is currently under investigation to understand what other pathways are affected by Cu-TA treatment.

Because of our successful results in the in vitro assays, a pilot study using a mouse model for PaCa was done to confirm our findings in an in vivo model. The $\mathrm{Cu}-\mathrm{TA}$ treatment dose dependently caused a decrease in tumor weights (25mg/kg: 48\%; $50 \mathrm{mg} / \mathrm{kg}: 68 \%$ ) (Fig. $7 \mathrm{~A}$ ). Apart from the reduction in tumor size and weight, there is also a visible decrease in tumor vasculature (Fig. 7A). This is significant since tumor vasculature is vital for tumor growth and survival [50]. Furthermore, there was no changes observed in the mice body weights (Fig. 7B), indicating that no obvious toxicity was occurring with $\mathrm{Cu}-\mathrm{TA}$ treatment.

In summary, $\mathrm{Cu}$-TA's $\mathrm{IC}_{50}$ dosage to inhibit cell proliferation was found to be half that of TA demonstrating higher efficacy and the growth inhibitory effect of $\mathrm{Cu}$-TA was attributed to cell cycle arrest; demonstrated by an increase of Panc1 cells in G2/M phase. Activation of apoptosis was also shown (by increasing effector caspase activity, cleaved PARP 


\section{Cellular Physiology Cell Physiol Biochem 2018;51:1894-1907

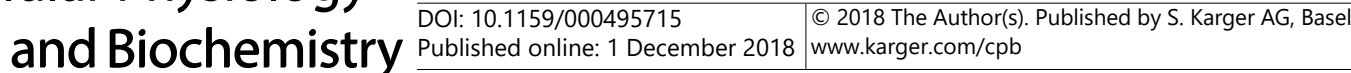 \\ Hurtado et al.: Novel Survivin Inhibitor for Suppressing Pancreatic Cancer Cells}

protein expression and apoptotic cell populations) and may contribute to the inhibition of proliferation. Molecular regulators that drive tumorigenesis and resistance, Sp1 and Sp3, were downregulated with $\mathrm{Cu}$-TA. Expression of one of their targets, survivin, was also found to be significantly decreased. While we see a trend in inhibition of Sp1 and Sp3, the most responsive marker is survivin, with MIA PaCa-2 having $82.8 \%$ protein inhibition and Panc1 $86.7 \%$ (Fig. 2A\&B). This further supports that the anti-cancer activity seen with Cu-TA may be more associated with survivin. In the TA treatment, Sp1, Sp3 and survivin protein expression are all relatively unaffected. However, in the $\mathrm{Cu}$-TA treatment, the effect is higher in survivin when compared to Sp1 and Sp3. Cu-TA was found to have a significant increase in survivin inhibition (MIA PaCa-2: 5.2-fold; Panc1: 6.4-fold) compared to TA. Both Sp1 and Sp3 regulate survivin and can inhibit or activate its expression. If the downregulation of survivin is through Sp proteins inhibition (post-translational degradation), then the effect observed is an additive response. However, other mechanisms could be involved and pathway analysis of $\mathrm{Cu}$-TA treatment in PaCa cells is currently under investigation.

\section{Conclusion}

In conclusion, survivin is a tangible marker to target for treating cancers due to its strong association with tumorigenesis and resistance to therapy and the specific agents to target survivin are still under investigation. In this investigation, $\mathrm{Cu}$-TA showed anti-cancer activity in PaCa cells and had an enhanced efficacy in comparison to TA via inhibiting survivin. Finding a potent inhibitor of survivin for PaCa treatment is just as vital as finding a non-toxic and stable agent. The growth inhibitor effect seen in our in vitro studies were reproducible in our mouse model for PaCa. Recent findings from our group [36] demonstrated the stable biological (anti-proliferative activity against PaCa cells) and structural stability as characterization by FTIR and UV-visible spectroscopy for up to 12 months. Additionally, CuTA did not cause any significant cytotoxicity in cardiomyocytes [36]. The cardiomyocyte data along with our mouse model results provides preliminary evidence that $\mathrm{Cu}$-TA is non-toxic to non-malignant cells. The ultimate goal of investigating $\mathrm{Cu}$-TA would be to use this alongside standard treatment care. By downregulating survivin, we hope to sensitize the cancer cells to treatment. Therefore, allowing the patients to receive less chemotherapy and radiation for less side effects without compromising therapeutic efficacy. Further testing is required, but this provides preliminary evidence for the potential use of $\mathrm{Cu}-\mathrm{TA}$ in $\mathrm{PaCa}$ treatment.

\section{Acknowledgements}

This research is partially supported by a grant from Shirley E Noland Foundation (RB). JKV is supported by National Institutes of Minority Health and Health Disparities (grant \# P20 MD006882 and grant \# 2U54 MD006882-06).

\section{Disclosure Statement}

The authors have no conflicts of interest in this research.

\section{References}

1 Siegel RL, Miller KD, Jemal A: Cancer Statistics, 2017. CA Cancer J Clin 2017;67:7-30.

-2 Khan MA, Azim S, Zubair H, Bhardwaj A, Patel GK, Khushman M, Singh S, Singh AP: Molecular Drivers of Pancreatic Cancer Pathogenesis: Looking Inward to Move Forward. Int J Mol Sci 2017;18:E779.

3 Khan MA, Zubair H, Srivastava SK, Singh S, Singh AP: Insights into the Role of microRNAs in Pancreatic Cancer Pathogenesis: Potential for Diagnosis, Prognosis, and Therapy. Adv Exp Med Biol 2015;889:71-87. Goral V: Pancreatic Cancer: Pathogenesis and Diagnosis. Asian Pac J Cancer Prev 2015;16:5619-5624. Bliss LA, Witkowski ER, Yang CJ, Tseng JF: Outcomes in operative management of pancreatic cancer. J Surg Oncol 2014;110:592-598. 


\section{Cellular Physiology Cell Physiol Biochem 2018;51:1894-1907 \begin{tabular}{l|l|l} 
and Biochemistry & $\begin{array}{l}\text { DOI: 10.1159/000495715 } \\
\text { Published online: 1 December } 2018\end{array}$ & $\begin{array}{l}\text { @ } 2018 \text { The Author(s). Published by S. Karger AG, Basel } \\
\text { www.karger.com/cpb }\end{array}$
\end{tabular}}

6 Thota R, Pauff JM, Berlin JD: Treatment of metastatic pancreatic adenocarcinoma: a review. Oncology (Williston Park) 2014;28:70-74.

7 Fotopoulos G, Syrigos K, Saif MW: Genetic factors affecting patient responses to pancreatic cancer treatment. Ann Gastroenterol 2016;29:466-476.

-8 Ansari D, Gustafsson A, Andersson R: Update on the management of pancreatic cancer: surgery is not enough. World J Gastroenterol 2015;21:3157-3165.

9 Miller RP, Tadagavadi RK, Ramesh G, Reeves WB: Mechanisms of Cisplatin nephrotoxicity. Toxins (Basel) 2010;2:2490-2518.

10 Oberstein PE, Olive KP: Pancreatic cancer: why is it so hard to treat? Therap Adv Gastroenterol 2013;6:321337.

11 Amrutkar M, Gladhaug IP: Pancreatic Cancer Chemoresistance to Gemcitabine. Cancers (Basel) 2017;9:E157.

12 Cheung $\mathrm{CH}$, Cheng L, Chang KY, Chen HH, Chang JY: Investigations of survivin: the past, present and future. Front Biosci (Landmark Ed) 2011;16:952-961.

13 Boidot R, Vegran F, Lizard-Nacol S: Transcriptional regulation of the survivin gene. Mol Biol Rep 2014;41:233-240.

14 Santa Cruz Guindalini R, Mathias Machado MC, Garicochea B: Monitoring survivin expression in cancer: implications for prognosis and therapy. Mol Diagn Ther 2013;17:331-342.

15 Jaiswal PK, Goel A, Mittal RD: Survivin: A molecular biomarker in cancer. Indian J Med Res 2015;141:389397.

16 Satoh K, Kaneko K, Hirota M, Masamune A, Satoh A, Shimosegawa T: Expression of survivin is correlated with cancer cell apoptosis and is involved in the development of human pancreatic duct cell tumors. Cancer 2001;92:271-278.

17 Lee MA, Park GS, Lee HJ, Jung JH, Kang JH, Hong YS, Lee KS, Kim DG, Kim SN: Survivin expression and its clinical significance in pancreatic cancer. BMC Cancer 2005;5:127.

18 Asanuma K, Moriai R, Yajima T, Yagihashi A, Yamada M, Kobayashi D, Watanabe N: Survivin as a radioresistance factor in pancreatic cancer. Jpn J Cancer Res 2000;91:1204-1209.

19 Kami K, Doi R, Koizumi M, Toyoda E, Mori T, Ito D, Kawaguchi Y, Fujimoto K, Wada M, Miyatake S, Imamura M: Downregulation of survivin by siRNA diminishes radioresistance of pancreatic cancer cells. Surgery 2005;138:299-305.

-20 Abdelrahim M, Baker CH, Abbruzzese JL, Safe S: Tolfenamic acid and pancreatic cancer growth, angiogenesis, and Sp protein degradation. J Natl Cancer Inst 2006;98:855-868.

-21 Basha R, Ingersoll SB, Sankpal UT, Ahmad S, Baker CH, Edwards JR, Holloway RW, Kaja S, Abdelrahim M: Tolfenamic acid inhibits ovarian cancer cell growth and decreases the expression of c-Met and survivin through suppressing specificity protein transcription factors. Gynecol Oncol 2011;122:163-170.

-22 Eslin D, Lee C, Sankpal UT, Maliakal P, Sutphin RM, Abraham L, Basha R: Anticancer activity of tolfenamic acid in medulloblastoma: a preclinical study. Tumour Biol 2013;34:2781-2789.

-23 Shelake S, Sankpal UT, Paul Bowman W, Wise M, Ray A, Basha R: Targeting specificity protein 1 transcription factor and survivin using tolfenamic acid for inhibiting Ewing sarcoma cell growth. Invest New Drugs 2017;35:158-165.

24 Konduri S, Colon J, Baker CH, Safe S, Abbruzzese JL, Abudayyeh A, Basha MR, Abdelrahim M: Tolfenamic acid enhances pancreatic cancer cell and tumor response to radiation therapy by inhibiting survivin protein expression. Mol Cancer Ther 2009;8:533-542.

-25 Hedrick E, Cheng Y, Jin UH, Kim K, Safe S: Specificity protein (Sp) transcription factors Sp1, Sp3 and Sp4 are non-oncogene addiction genes in cancer cells. Oncotarget 2016;7:22245-22256.

26 Jiang NY, Woda BA, Banner BF, Whalen GF, Dresser KA, Lu D: Sp1, a new biomarker that identifies a subset of aggressive pancreatic ductal adenocarcinoma. Cancer Epidemiol Biomarkers Prev 2008;17:1648-1652.

27 Xu R, Zhang P, Huang J, Ge S, Lu J, Qian G: Sp1 and Sp3 regulate basal transcription of the survivin gene. Biochem Biophys Res Commun 2007;356:286-292.

28 Holder AA: Inorganic pharmaceuticals. Annu Rep Prog Chem, Section A: Inorg Chem 2012;108:350-368.

29 Holder AA: Inorganic pharmaceuticals. Annu Rep Prog Chem, Section A: Inorg Chem 2013;109:317-339.

-30 Holder AA, Taylor P, Magnusen AR, Moffett ET, Meyer K, Hong Y, Ramsdale SE, Gordon M, Stubbs J, Seymour LA, Acharya D, Weber RT, Smith PF, Dismukes GC, Ji P, Menocal L, Bai F, Williams JL, Cropek DM, Jarrett WL: Preliminary anti-cancer photodynamic therapeutic in vitro studies with mixed-metal binuclear ruthenium(II)-vanadium(IV) complexes. Dalton Trans 2013;42:11881-11899. 


\section{Cellular Physiology Cell Physiol Biochem 2018;51:1894-1907

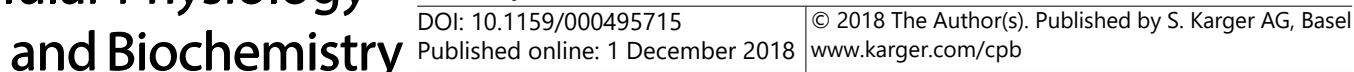

31 Kumar K, Schniper S, Gonzalez-Sarrias A, Holder AA, Sanders N, Sullivan D, Jarrett WL, Davis K, Bai F, Seeram NP, Kumar V: Highly potent anti-proliferative effects of a gallium(III) complex with 7-chloroquinoline thiosemicarbazone as a ligand: synthesis, cytotoxic and antimalarial evaluation. Eur J Med Chem 2014;86:81-86.

-32 Lewis NA, Liu F, Seymour L, Magnusen A, Erves TR, Arca JF, Beckford FA, Venkatraman R, Gonzalez-Sarrias A, Fronczek FR, Vanderveer DG, Seeram NP, Liu A, Jarrett WL, Holder AA: Synthesis, characterization, and preliminary in vitro studies of vanadium(IV) complexes with a Schiff base and thiosemicarbazones as mixed-ligands. Eur J Inorg Chem 2012;2012:664-677.

-33 Sandhaus S, Taylor R, Edwards T, Huddleston A, Wooten Y, Venkatraman R, Weber RT, Gonzalez-Sarrias A, Martin PM, Cagle P, Tse-Dinh YC, Beebe SJ, Seeram N, Holder AA: A novel copper(II) complex identified as a potent drug against colorectal and breast cancer cells and as a poison inhibitor for human topoisomerase IIalpha. Inorg Chem Commun 2016;64:45-49.

34 Crisponi G, Nurchi V, D. F, Gerosa C, Nemolato S, Faa G: Copper-related diseases: From chemistry to molecular pathology. Coordination Chemistry Reviews 2010;254:876-889.

35 Tarushi A, Perontsis S, Hatzidimitriou AG, Papadopoulos AN, Kessissoglou DP, Psomas G: Copper(II) complexes with the non-steroidal anti-inflammatory drug tolfenamic acid: Structure and biological features. J Inorg Biochem 2015;149:68-79.

-36 Hurtado M, Sankpal U, Chhabra J, Brown D, Maram R, Patel R, Gurung R, Simecka J, Holder A, Basha R: Copper-tolfenamic acid: Evaluation of stability and anti-cancer activity. Invest New Drugs 2018;10.1007/ s10637-018-0594-9.

-37 Adamska A, Elaskalani O, Emmanouilidi A, Kim M, Abdol Razak NB, Metharom P, Falasca M: Molecular and cellular mechanisms of chemoresistance in pancreatic cancer. Adv Biol Regul 2017;10.1016/j. jbior.2017.11.007

38 Basha R, Baker CH, Sankpal UT, Ahmad S, Safe S, Abbruzzese JL, Abdelrahim M: Therapeutic applications of NSAIDS in cancer: special emphasis on tolfenamic acid. Front Biosci (Schol Ed) 2011;3:797-805.

-39 Rayburn ER, Ezell SJ, Zhang R: Anti-Inflammatory Agents for Cancer Therapy. Mol Cell Pharmacol 2009;1:29-43.

40 Kumar S, Stokes J, 3rd, Singh UP, Scissum Gunn K, Acharya A, Manne U, Mishra M: Targeting Hsp70: A possible therapy for cancer. Cancer Lett 2016;374:156-166.

41 Bhardwaj A, Singh S, Singh AP: MicroRNA-based Cancer Therapeutics: Big Hope from Small RNAs. Mol Cell Pharmacol 2010;2:213-219.

-42 Thun MJ, Henley SJ, Patrono C: Nonsteroidal anti-inflammatory drugs as anticancer agents: mechanistic, pharmacologic, and clinical issues. J Natl Cancer Inst 2002;94:252-266.

-43 Fosslien E: Cardiovascular complications of non-steroidal anti-inflammatory drugs. Ann Clin Lab Sci 2005;35:347-385.

44 Sankpal UT, Lee CM, Connelly SF, Kayaleh O, Eslin D, Sutphin R, Goodison S, Adwan L, Zawia NH, Lichtenberger LM, Basha R: Cellular and organismal toxicity of the anti-cancer small molecule, tolfenamic acid: a pre-clinical evaluation. Cell Physiol Biochem 2013;32:675-686.

-45 Vermes I, Haanen C, Steffens-Nakken H, Reutelingsperger C: A novel assay for apoptosis. Flow cytometric detection of phosphatidylserine expression on early apoptotic cells using fluorescein labelled Annexin V. J Immunol Methods 1995;184:39-51.

46 Casimiro MC, Crosariol M, Loro E, Li Z, Pestell RG: Cyclins and cell cycle control in cancer and disease. Genes Cancer 2012;3:649-657.

47 Viallard JF, Lacombe F, Belloc F, Pellegrin JL, Reiffers J: [Molecular mechanisms controlling the cell cycle: fundamental aspects and implications for oncology]. Cancer Radiother 2001;5:109-129.

48 Yam CH, Fung TK, Poon RY: Cyclin A in cell cycle control and cancer. Cell Mol Life Sci 2002;59:1317-1326.

49 Senderowicz AM, Sausville EA: Preclinical and clinical development of cyclin-dependent kinase modulators. J Natl Cancer Inst 2000;92:376-387.

-50 Forster JC, Harriss-Phillips WM, Douglass MJ, Bezak E: A review of the development of tumor vasculature and its effects on the tumor microenvironment. Hypoxia (Auckl) 2017;5:21-32 